International Journal of Child, Youth and Family Studies (2020) 11(4.2): 80-95

DOI: $10.18357 /$ ijcyfs 114.2202019989

\title{
RESIDENTIAL CARE IN GERMANY FOR REFUGEE YOUNG PEOPLE
}

\section{Norbert Struck}

\begin{abstract}
This article analyzes developments in the forms of social work with young refugees and the legal framing of such work in Germany from 1990 to the present. In particular, it addresses the reactions of politicians and the child and youth welfare system to the sharp rise in the number of refugees in 2015 and 2016, and the concomitant significant increase in the number of unaccompanied minor refugees. It underlines the need for an approach based on children's rights, and the necessity for social workers, especially those involved in helping youth, to resist the policies of deterrence that are aimed at keeping refugees out of Germany.
\end{abstract}

Keywords: young refugees, unaccompanied minor refugees; children's rights; Child and Youth Care Act - SGB VIII

Norbert Struck Dipl. Pädagoge is a member of IGfH, the German section of FICE, is the former Youth Welfare Officer of the Paritätischer Wohlfahrtsverband, Germany, and was the Chairman of the Arbeitsgemeinschaft für Kinder- und Jugendhilfe - AGJ Germany [German Child and Youth Welfare Association] from 2006 to 2012. Email: norbert-struck@t-online.de

Acknowledgement: With a big thank you to George Austin-Cliff of the German Youth Institute (DJI), who helped me so much. The diction of this article follows the lecture. 
When we consider the situation of refugee young people in Germany, we have to take into account that Germany is an immigrant society. About $25 \%$ of young people in Germany have a migration background; however, in big cities — such as Berlin, Cologne, Munich, and Hamburg - this rises to half. On the other hand, in some of the districts, especially in East Germany, most people have hardly any experience with immigrants. As shown in Table 1, the likelihood of people having a migration background decreases somewhat with age, as does the likelihood of those with a migration background having German citizenship.

Table 1. Population With and Without Migration Background by Age in Germany, 2019.

\begin{tabular}{lcccccccc}
\hline \multirow{2}{*}{ Status } & \multicolumn{2}{c}{ Total } & & \multicolumn{2}{c}{$0-10$ years } & & \multicolumn{2}{c}{$10-20$ years } \\
\cline { 2 - 3 } & No. & $\%$ & & No. & $\%$ & & No. & $\%$ \\
\hline People without migration background & 60.814 & 74 & & 4.310 & 60 & & 4.901 & 64 \\
People with migration background & 20.799 & 25 & & 2.910 & 40 & & 2.747 & 36 \\
$\quad$ German citizen & 10.892 & 13 & & 2.032 & 28 & & 1.904 & 25 \\
$\quad$ Not German citizen & 9.907 & 12 & & 0.879 & 13 & & 0.833 & 11 \\
\hline
\end{tabular}

Note. Population numbers are in millions. Data from DeStatis-Statistisches Bundesamt (2020); own calculations.

The most vulnerable group of young people in terms of participation, education, and the uncertainty of their residence status are those without nationality in one of the European Union Countries: young refugees. The period from 2015 to 2016 was not the first in which the number of refugees entering Germany rapidly increased. Due to the Yugoslav Wars, there were as many refugees in 1992 as in 2015.(Bundesamt für Migration und Flüchtlinge, 2015, p. 8; Bundeszentrale für politische Bildung, 2005, p. 1). We can also be sure that such challenges for the child and youth welfare system in Germany can recur at any time: we must do better at anticipating such situations. We are failing in Moria, Lampedusa, and the Mediterranean Sea. (Meinhold, J., 2020). But if Europe is going to take responsibility for these young refugees the German child and welfare system must be prepared.

According to estimates by the office of the United Nations High Commissioner for Refugees (UNHCR), $40 \%$ of all refugees worldwide are minors - more than 32 million young people (UNHCR, 2020). Mostly they flee with their parents or family members; but sometimes they are separated while on the run and become unaccompanied minor refugees (UMRs):

Many children move alone and face particularly grave risks. In parts of the world, the number of children moving on their own has skyrocketed. On the dangerous Central Mediterranean Sea passage from North Africa to Europe, 92 per cent of children who arrived in Italy in 2016 and the first two months of 2017 were unaccompanied, up from 75 per cent in 2015. At least 300,000 unaccompanied and separated children moving across borders were registered in 80 countries in 20152016 - a near fivefold increase from 66,000 in 2010-2011. The total number of 
International Journal of Child, Youth and Family Studies (2020) 11(4.2): 80-95

unaccompanied and separated children on the move worldwide is likely much higher. (UNICEF, 2017a, p. 6; see also UNICEF, 2017b)

Europe sees only a fraction of these refugees. The vast majority have to endure very difficult conditions in countries neighbouring their homelands. Syrian refugees, for example, have fled to countries like Turkey, Lebanon, and Jordan (Mediendienst Integration, 2020).

\section{Accompanied Young Refugees in Germany: Figures and Problems}

In 2015 and 2016 about 350,000 children came to Germany accompanied by their parents or by relatives who took care of them (UNHCR 2020). Like all children, young people who flee to Germany with their parents have - or should have - the right to protection, promotion (i.e., development), and participation. However, many families are accommodated in a reception facility or in a Lager [warehouse] — a shared accommodation camp — where they face dangerous situations and are excluded from many rights (Terre des hommes, n.d., pp. 4-11).

In the reception areas in Germany, most refugees have as little as 6 square meters of living space per person (Wikipedia, 2020). In the Lager, about $75 \%$ have less than 9 square meters per person. Although these Lager are not a child-friendly environment, for many of the minors they are the center of life for months, or even years. The lack of either privacy or safe places to serve as retreats means that children do not have quiet places to learn or to play, and are instead confronted with threats and violence, including sexual abuse (Bundesfachverband unbegleitete minderjährige Flüchtlinge [BumF], 2013). To make matters worse, the children do not typically attend regular schools (Paritätischer Gesamtverband, 2019).

On the other side, we have to realize that about $5 \%$ of all instances of Inobhutnahme [taking into care] in Germany are because of "housing problems", living conditions which are insufficient for the childs well-being (DeStatis, 2019, Struck, 2014, p. 22). The German authorities know that there are problems of child well-being related to the living situation but they don't relate it to the housing problems of young refugees in initial reception facilities and shared accommodations.

\section{UMRs - A Short History of the Legal Framing}

Besides the European Union regulations - for example, the "Reception Condition Directive 2013/33/EU" of June 2013 (Europäische Union, 2013), which is taken into account when receiving persons who apply for international protection - there are many laws and other legal framings that relate to the situation of UMRs in Germany. The most important of them are the Social Code Book VIII (Child and Youth Care Act - SGB VIII; Sozialgesetzbuch VIII, n.d.), the Asylum Act (Bundesamt für Justiz, 1992), and the Residence Act (Bundesministerium des Inneren, n.d.). Over the years there have been some changes in the corresponding law that I regard as positive:

- 1990: Two new sections were created $\S 42,43$ SGB VIII: Inobhutnahme [taking into (state or social services) care], which covered all children, and thereby included UMRs, but they were not explicitly mentioned in the law. 
International Journal of Child, Youth and Family Studies (2020) 11(4.2): 80-95

- 2005: The first amendment in $\S 42$ subsection 1 SGB VIII altered its text to state explicitly that the child and youth welfare system must take care of UMRs.

- 2015: New subsections a to $\mathrm{f}$ were added to $\S 42$ SGB VIII. These specified new regulations for provisionally taking UMRs into care, and new special regulations for taking non-UMR children and youth into care.

Under the additions to Section 42 in 2015, UMRs are to be provisionally taken into care by the youth welfare office that has local responsibility. This provisional taking into care ensures that they are accommodated with a suitable person or — more often — in a so-called suitable facility. Suitable persons can be relatives or foster families, while suitable facilities are as a rule either "clearing houses" specialising in caring for UMRs, or youth welfare facilities.

During the provisional taking into care, an initial screening is carried out, consisting of an examination of the UMR's state of health and a determination of the UMR's age. A nationwide distribution procedure assigns each UMR to a youth office, which is then responsible for their further taking into care. Furthermore, a (legal) guardian or curator must be appointed for unaccompanied minors by a family court: the youth welfare office must apply for a guardianship to be set up within 4 weeks or at the start of regular care (Bundesverwaltungsgericht, 1999).

- In 2015, the $\S 80$ Residence Act was changed: the age of eligibility to represent oneself during the administrative procedure was raised from 16 to 19 (Bundesministerium für Familie, Senioren, Frauen und Jugend, 2015, p. 1805). In consequence, all minors now receive assistance as they go through the asylum procedure.

The changes in national law that I have been discussing are framed by regulations of international law, especially the United Nations Convention on the Rights of the Child (CRC; 1989), which was implemented in Germany on April 5, 1992. However, the federal states of the Federal Republic of Germany agreed to sign the CRC only if the government put forward a declaration concerning the following articles, a "design reserve":

- Article 9 Separation from the parents

- Article 10 Family reunion

- Article 18 Responsibility for the well-being of the child

- Article 22 Refugee children

This design reserve is in regard to the rights of young refugees. Germany at that time used Abschiebehaft [detention] against young refugees. Germany did not want to stop this practice, nor did Germany want to allow children the right to have their parents also settle in Germany. The German interpretation was: Immigration law has priority over children's rights. 
International Journal of Child, Youth and Family Studies (2020) 11(4.2): 80-95

In Germany at that time, young people of 16 years were regarded as able to handle legal procedures relating to their residence status on their own without a legal guardian, despite the complexities presented by the many different types of residence status in Germany:

- Aufenthaltsgestattung (suspension of deportation; the lowest type),

- Aufenthaltserlaubnis (issued for an educational, humanitarian, or similar reason),

- Aufenthaltsduldung (temporary suspension of the deportation of foreigners required to leave the country), and

- Niederlassungserlaubnis (right of establishment; the highest type).

As it is difficult even to translate these words to English in a way that captures the distinctions between the different types of permit, there is clearly little chance for a UMR who does not speak much German to get an idea what the authorities are saying, even if he or she is able to speak English.

Opposition to forcing young people to handle their own legal procedures emerged from the civil societies that deal with children's rights and the rights of young refugees. These were aggregated in the National Coalition Germany ${ }^{1}$ (n.d.), which formed part of the network for the implementation of the CRC.

On July 15, 2010 Germany withdrew the design reserve. This was a great victory for all those who were engaged in the opposition against the design reserve. We hoped that this would finally signal to German society and politics that:

- the human rights of young refugees must be respected and upheld by the child and youth welfare system;

- the activities of the youth welfare system must have priority over the intentions of internal politics; and,

- the best interests of the child — the child's well-being — must be the leading criterion.

\section{The Situation in 2015}

The increasing number of refugees that came to Europe, and especially to Germany, in 2015 found the nation unprepared: the influx became a crisis. (Bundesamt für Migration und Flüchtlinge, 2016, pp. 10-23) The first priority of crisis-management was to organize emergency shelter, food, and elementary medical aid. UMRs were subject to the redistribution process mentioned above, which meant that some were sent to facilities with experience and knowledge, while others were sent to rural towns and hostels, where no professionals were available with experience in the care of young people, especially those who — like many UMRs — have been

\footnotetext{
${ }^{1}$ https://www.netzwerk-kinderrechte.de/en.html
} 
International Journal of Child, Youth and Family Studies (2020) 11(4.2): 80-95

severely traumatized. Other difficulties could also arise in the rural locations; for example, UMRs sent to villages lacking a stable internet connection had difficulty keeping in touch with relatives.

Under German law, minors have to be taken into social services care when their well-being is at risk. Since UMRs are a group at risk, they have to be taken into state care by the youth authorities, who, according to $\S 36$ SGB VIII, must provide them with shelter, protection, and a care plan. Official figures from 2013 to 2018 provide an impression of the challenges faced by the German child and youth welfare system during this period (see Table 2).

Table 2. Youth Taken into Care by the Child and Youth Welfare System

\begin{tabular}{ccrc}
\hline Year & Total & UMRs & \% of UMRs \\
\hline 2013 & 42,123 & 6,584 & 15.6 \\
2014 & 48,059 & 11,642 & 24.2 \\
2015 & 77,645 & 42,900 & 55.2 \\
2016 & 84,230 & 44,900 & 53.3 \\
2017 & 61,383 & 22,500 & 36.7 \\
2018 & 52,590 & 12,211 & 23.2 \\
\hline
\end{tabular}

Note. Figures from Mühlmann (n.d.).

In 2015, about 137,500 minor refugees reached Germany (UNICEF, 2018); almost two thirds of them were accompanied. In certain towns and areas where the concentration of people arriving was especially high, the residents and authorities were hard pressed to supply elementary shelter, food, clothing, and protection. In civil society, structures for coordinating the willingness of citizens to get involved have been expanded and diverse offers of support for refugees have emerged. At the same time, the issues of integration and participation has come to the fore in the social debate. It's not just about welcoming and looking after the refugees, but about crafting national policies regarding asylum and immigration.

However, many cities and federal states were hardly affected by the situation and accumulated almost no experience in meeting the needs of young refugees.

Article 4 of the Gesetz zur Verbesserung der Unterbringung, Versorgung und Betreuung ausländischer Kinder und Jugendlicher (2015; Bundesministerium für Familie, Senioren, Frauen und Jugend, 2017) required that the outcomes of this situation and the handling of the "problem" of the UMRs be evaluated:

Art. 4: "The Federal Government must investigate the effects of this law and report to the German Bundestag by 31.12.2020 on the results of this investigation." And $\S 42$ e SGB VIII says: "The Federal Government has to submit to the German Bundestag a report every year on the situation of unaccompanied foreign minors."

Only patchy data are available on what happened to the young people in federal states that had previously taken little care of refugees (Kopp et al., 2016). There is much that we don't know, and 
International Journal of Child, Youth and Family Studies (2020) 11(4.2): 80-95

unfortunately I can only assume that we have been deliberately kept in the dark, in order to make arguments in favour of changing laws and practices more difficult to mount. We know that in several towns the refugees were exposed to xenophobic and racist violence (see, e.g., Wikipedia, 2018, 2019).In regard to UMRs involved in such incidents, no precise information is available about what happened and what lessons were learned. We do know, that, in some cases the UMRs have simply been relocated or have been sanctioned (Peters, 2016; Struck, 2017).

\section{Excursus: Trafficking and the Discourses about Illegal Behavior among Young Refugees}

In Germany, discourses about illegal behavior among young refugees are becoming more common (Bundeszentrale für politische Bildung, 2020). Young refugees are increasingly seen as actual or potential criminals rather than as children with human rights, who often have been victims of severe crimes (Willems, 2020). I focus on three aspects of such behavior (Struck, 2019, p. 3):

1. Deviant behavior among adolescents is a ubiquitous phenomenon, and thus is necessarily found among young refugees. It is also transitory, however.

2. Research has shown that a number of factors favor or encourage deviant behavior among adolescents (Dollinger, 2018), such as experience of violence, social isolation, lack of ressources, and no optimism refering to the future, and it is vital to emphasize that young refugees - especially those who arrive unaccompanied or as young adults - often have had high levels of exposure to these factors. Also, the conditions in the Lager prevent privacy, promote violence, promote social isolation, cut off resources, and, above all, destroy the young refugees' reasonable hopes for the future (Meinhold, 2019). In such conditions it is actually rather surprising that most of the young people, in my experience, still keep their motivation and show great willingness to integrate.

3. The facilities hosting UMRs are also sometimes required to accommodate young people who have been victims of trafficking. Trafficking includes "exploitation of the prostitution of others or other forms of sexual exploitation, forced labour or services, slavery or practices similar to slavery, servitude or the removal of organs" (United Nations Office on Drugs and Crime, 2004, p. 42). The exploitation of criminal activities of young people is mostly difficult to recognize. In my experience, social workers often struggle to endure the distancing of these young people and feel exploited by them, although in reality it is the young people who have been exploited by the traffickers. (Döcker \& Stamm, 2015, p. 4) In Germany, ECPAT Deutschland ${ }^{2}$ the national branch of the international ECPAT organization, which specializes in addressing the sexual exploitation of children - assists in dealing with these problems. When faced with trafficking, you cannot protect a child on your own. You need cooperation, support, and advice, and, above all, you need to stay connected to the child and not to reject him or her in frustration.

${ }^{2}$ https://ecpat.de/ 
International Journal of Child, Youth and Family Studies (2020) 11(4.2): 80-95

\section{Problems Arising After 2015}

In order to deal with the large number of young refugees who had suddenly appeared starting in 2015, the care standards in the facilities for UMRs were lowered on a "temporary basis" (BumF, 2017, p. 15). More and more facilities were designated as special units for UMRs: it was estimated that by the end of 2016 about $75 \%$ of facilities housing UMRs were specialized (Deutscher Bundestag, 2017, p. 72) for that purpose. There was a high level of engagement in civil society by welfare organizations and the youth welfare authorities, but there were also people and companies looking only for extra profit. Peters (2018), among others, objected to the privatization of refugee care under the company "European Homecare" (see also taz, 2019).

Today, we still have to deal with the consequences of the years 2015 and 2016 (Struck, 2016). In some regions, there has been hardly any experience of working and living together with UMRs; and even in regions with a more multicultural environment where there has been more contact with UMRs, facilities with good accommodation and professional care and support are not being fully used. Going forward, we need:

- To reinstate uniform standards of quality of care for young people;

- To create competence centers - professional facilities focused on supplying all the needs of young refugees - in all 16 federal states, rather than go on with simply numerical redistribution of UMRs to about 600 local youth welfare offices; and

- To counteract the increasing exclusion and separation of young refugees.

\section{Basic Needs and Special Needs of UMRs: Inclusion or Exclusion by Special Arrangements}

In general, I believe that, beyond their basic needs, all young people need recognition, respect, and opportunities for participation. But I believe, too, that every young person has particular needs resulting from his or her life experiences, traumas, talents, illnesses, disabilities, and other incidental characteristics. The balance between answering general and particular needs must be managed by every service provided by the child and youth welfare system.

But what follows? Are communal living arrangements in any case the method of choice? Should special provisions for UMRs generally be abolished? I think we should recognize by now that that would not be a correct answer. I believe, for example, that we should differentiate between urban and rural areas. In cities, common facilities should be the rule. In rural areas, on the other hand, with regard to the young people's security, schooling, and social well-being, distributing them among multiple institutions may not always be appropriate. Rather, it may be more effective to make special provision for the young refugees, with a focus on helping them to manage better in everyday life, cope with the demands of school, and deal with language problems. For example, the Alreju-Projekt ${ }^{3}$ in Brandenburg has created three group-living facilities, as well as places for youth requiring supervision, for UMRs. Of course, this is not to be applied without due

${ }^{3}$ https://diakonie-ols.de/alreju.html 
International Journal of Child, Youth and Family Studies (2020) 11(4.2): 80-95

consideration, but professionals should be encouraged to look for optimal arrangements in each case and to orient youth welfare planning processes to each youth's specific requirements.

Of course, some argue for specialization in order to save costs. The essence of their attitude seems to be that, "Those who have proven strong enough to escape to Germany as refugees just need a bit of help to integrate, so we can get by with providing a modest and cost-effective level of youth social work." In reality, this translates into a cost-driven claim that the need for care in these special facilities is particularly low, and thus fees can be low as well. Approaches like these could only be formulated by people who never have come into direct contact with escaped young women and men.

German domestic policy in regard to UMRs seems to be based on the idea that the authorities are justified in putting children and adolescents' lives on hold until their residential status has been decided, and then either deporting them or setting them at last upon a path to a life in Germany. But for children, every day counts: they need continual opportunities to grow, to learn, to develop, and to gain confidence about the future. Their lives cannot be paused. Therefore, it is imperative that the child and youth welfare system fight for the children and young people's right to every single day of their lives.

\section{Broader Issues}

This leads to more general questions (Struck, 2017). Can the child and youth welfare system remain true to its responsibility to safeguard and uphold the human rights of children and young people and resist becoming complicit in politics and its deterrence-based system? ${ }^{4}$ Is the child and youth welfare system able to enforce the right to education for all young people? Can it enforce children's right to family reunification? Can we manage to uphold the priority of the child and youth welfare system with regard to responsibility for UMRs, or will domestic politics continue to encroach on that power? Is the child and youth welfare system able to take care of the thousands of children and young people in the reception camps and give their families the support they need to deal with the new situation and challenges?

I would like to offer the following specific recommendations for policies affecting UMRs:

- For each UMR, a decision is made as to whether he or she comes under the protection of the CRC (i.e., is under the age of 18 years). This age determination must be kept in the hands of the child and youth welfare system and not entrusted to institutions that are not primarily committed to child welfare.

- UMRs should no longer be distributed throughout all 600 urban and rural locations of the local youth welfare offices. Instead, they should be placed in a sufficient number of

\footnotetext{
${ }^{4}$ On this complicated tension, see Gonzalez Mendesz de Vigo (2019)
} 
International Journal of Child, Youth and Family Studies (2020) 11(4.2): 80-95

competence centers with adequate professional standards, qualified personnel, a large pool of translators, and access to the internet and thus also to their communities of origin.

- The effective and successful participation of UMRs in all decisions made about them and for them is urgently needed. This will require a sufficient number of well-qualified language and cultural mediators.

- The UMRs must be able to rely on the child and youth welfare system to practise a policy of non-cooperation with authorities who are preparing or carrying out deportations.

- More resources should be made available for the provision of interculturally competent therapeutic services for traumatized young refugees. Care must be taken, however, not to stigmatize all young refugees as "sick".

- UMRs need an environment in which they can quickly develop realistic, hopeful, life perspectives. They need to believe that their efforts will have a worthwhile outcome.

Above all, I would urge the German child and youth welfare system to secure the international and national rights of both unaccompanied and accompanied young refugees, resisting the challenges of domestic policies, and of politicians who use various policies of deterrence in their attempts to keep refugees, including young refugees, out of Germany. Young refugees have a right of participation, provision, and protection from the very beginning. Germany has to fulfil its obligation to implement these rights - even when some European Union member states refuse to acknowledge these rights of young people at all. 
International Journal of Child, Youth and Family Studies (2020) 11(4.2): 80-95

\section{References}

Autorengruppe Kinder- und Jugendhilfestatistik. (2019). Kinder- und Jugendhilfereport 2018: Eine Kennzalenbasierte Analyse [Child and Youth Welfare Report 2018: An analysis based on key figures]. Barbara Budrich.

Bundesamt für Justiz Asylgesetz [Asylum Act] (AsylG) of June 26, 1992. https://www.gesetzeim-internet.de/asylvfg_1992/BJNR111260992.html

Bundesamt für Migration und Flüchtlinge. (2015). Migrationsbericht 2015: Zentrale Ergebnisse [Migration Report 2015: Central Results]. https://www.bamf.de/SharedDocs/Anlagen/DE/Forschung/Migrationsberichte/migrationsberic ht-2015-zentrale-ergebnisse.pdf? blob=publicationFile \&v $=17$

Bundesamt für Migration und Flüchtlinge. (2016). Das Bundesamt in Zahlen 2015: Asyl, Migration und Integration [The Federal Office figures 2015: Asylum,. migration and integration].

https://www.bamf.de/SharedDocs/Anlagen/DE/Statistik/BundesamtinZahlen/bundesamt-in$\underline{\text { zahlen-2015.pdf? _blob=publicationFile } \& v=16}$

Bundesfachverband unbegleitete minderjährige Flüchtlinge. (2013). Kinder zweiter Klasse.

Bericht zur Lebenssituation junger Flüchtlinge in Deutschland [Second class children: Report on the life situation of young refugees in Germany]. https://b-umf.de/src/wpcontent/uploads/2018/01/Kinder-zweiter-Klasse-\%E2\%80\%93-Bericht-Zur-Lebenssituationjunger-Fl\%C3\%BCchtlinge-in-Deutschland-an-die-Vereinten-Nationen-.pdf

Bundesfachverband unbegleitete minderjährige Flüchtlinge. (2017). Die Aufnahmesituation unbegleiteter minderjähriger Flüchtlinge in Deutschland Erste Evaluation zur Umsetzung des Umverteilungsgesetzes [The reception situation of unaccompanied minor refugees in Germany: First evaluation of the implementation of the Redistribution Act]. https://bumf.de/src/wp-content/uploads/2017/12/aufnahmesituation_umf_2016.pdf

Bundesministerium des Inneren. (n.d.). Häufig gestellte Fragen zum Thema: Aufenthaltsrecht [Frequently asked questions: Right of residence]. https://www.bmi.bund.de/SharedDocs/faqs/DE/themen/migration/aufenthaltsrecht/aufenthalts recht-liste.html 
International Journal of Child, Youth and Family Studies (2020) 11(4.2): 80-95

Bundesministerium für Familie, Senioren, Frauen und Jugend. (2017). Gesetz zur Verbesserung der Unterbringung, Versorgung und Betreuung ausländischer Kinder und Jugendlicher [Law to improve the accommodation, care and support of foreign children and young people] from 28.10.2015; BGbL I 42, 1802-1806.

https://www.bgbl.de/xaver/bgbl/start.xav?startbk=Bundesanzeiger_BGBl\&jumpTo=bgbl115s 1802.pdf\#_bgbl_\%2F\%2F*\%5B\%40attr_id\%3D\%27bgbl115s1802.pdf\%27\%5D_160391 $\underline{3756200}$

Bundesverwaltungsgericht. Urteil verkündet am 24.06.1999 - Aktenzeichen: BVerwG 5 C 24/98 [Judgment announced on June 24th, 1999 - File number: BVerwG 5 C 25.98]. https://www.judicialis.de/Bundesverwaltungsgericht_BVerwG-5-C-2598_Urteil_24.06.1999.html

Bundeszentrale für politische Bildung [Federal Centre for Political Education]. (2005). Flucht und Asyl seit 1990 [Escape and asylum since 1990].

https://www.bpb.de/gesellschaft/migration/dossier-migration-ALT/56443/flucht-und-asyl$\underline{\text { seit-1990 }}$

Bundeszentrale für politische Bildung [Federal Centre for Political Education]. (2020). Migration und Kriminalität - Erfahrungen und neuere Entwicklungen: 5. Jugendkriminalität [Migration and crime — Experiences and recent developments: 5. Juvenile delinquency]. https://www.bpb.de/politik/innenpolitik/innere-sicherheit/301624/migration-undkriminalitaet\#\%E2\%80\%9E07\%E2\%80\%9C

DeStatis-Statistisches Bundesamt. (2019). Jugendämter leiten 2018 rund 52600 Inobhutnahmen zum Schutz Minderjähriger ein [In 2018, youth welfare offices will initiate around 52,600 children in care to protect minors; Pressemitteilung Nr. 308 vom 16. August 2019]. https://www.destatis.de/DE/Presse/Pressemitteilungen/2019/08/PD19_308_225.html

DeStatis-Statistisches Bundesamt. (2020). Migration und Integration: Bevölkerung mit Migrationshintergrund [Migration and integration: Population with a migration background]. https://www.destatis.de/DE/Themen/Gesellschaft-Umwelt/Bevoelkerung/MigrationIntegration/Publikationen/_publikationen-innen-migrationshintergrund.html

Deutscher Bundestag. (2017). Bericht über die Situation unbegleiteter ausländischer Minderjähriger in Deutschland [Report on the situation of unaccompanied foreign minors in Germany] (Drucksache 18/11540). http://dipbt.bundestag.de/doc/btd/18/115/1811540.pdf

Deutscher Bundestag. (2018). Bericht über die Situation unbegleiteter ausländischer Minderjähriger in Deutschland [Report on the situation of unaccompanied foreign minors in Germany] (Drucksache 19/4517). http://dipbt.bundestag.de/doc/btd/19/045/1904517.pdf. 
International Journal of Child, Youth and Family Studies (2020) 11(4.2): 80-95

Döcker, M., \& Stamm, I. (2015). Kinderhandel in Deutschland - Aufgabe und Herausforderung für die Kinder- und Jugendhilfe [Child trafficking in Germany; A task and challenge for child and youth welfare]. Nachrichtendienst des Deutschen Vereins, 4, 1-5.

Dollinger, B. (2018). Abweichendes Verhalten [Deviant behaviour]. In G. Graßhoff, A. Renker, \& W. Schröer (Eds.), Soziale Arbeit (pp. 69-81). Springer VS.

doi:10.1007/978-3-658-15666-4_6

Europäische Union. (2013). Reception Condition Directive 2013/33/EU” of June 26, 2013. https://eur-lex.europa.eu/legal-content/EN/TXT/?uri=celex\%3A32013L0033

Gonzalez Mendez de Vigo, N., \& Karpenstein, J. (2019). Junge Geflüchtete zwischen Jugendhilfe und ordnungsrechtlichen Paradigmen: Ein Appell an eine parteiliche Fachlichkeit [Young refugees between youth welfare and regulatory paradigms - an appeal to partisan professionalism]. Forum Erziehungshilfen, 5, 260-265.

Karpenstein, J., \& Klaus, T. (2019). Die Situation Unbegleiteter Minderjähriger Flüchtlinge in Deutschland. Auswertung der Online-Umfrage 2018 [The situation of unaccompanied minor refugees in Germany. Evaluation of the online survey 2018]. Bundesfachverband unbegleitete minderjährige Flüchtlinge. https://b-umf.de/src/wpcontent/uploads/2019/05/2019_05_20_auswertung-bumf-online-umfrage-2018.pdf

Katzenstein, H., Méndez de Vigo, N. G., \& Meysen, T. (2015). Das Gesetz zur Verbesserung der Unterbringung, Versorgung und Betreuung ausländischer Kinder und Jugendlicher. Ein erster Überblick [Law to improve the accommodation, care and support of foreign children and adolescents: A first overview]. Das Jugendamt,11, 530-537.

Kiepe, E., \& Pothmann, J. (2018). Unbegleitete Minderjährige in vorläufiger und regulärer Inobhutnahme [Unaccompanied minors in temporary and regular custody]. Kommentierte Daten der Kinder- und Jugendhilfe (KomDat), 2018/02, 15-19.

Kopp, K., Meiner-Teubner, C., \& Pothmann, J. (2016). Datenlage zu minderjährigen Flüchtlingen - viele Fragen bleiben offen [Data on refugee minors - many questions remain unanswered]. Forum Jugendhilfe, 1, 18-23.

Lechner, C., \& Huber, A. (2017). Ankommen nach der Flucht: Die Sicht begleiteter und unbegleiteter junger Geflüchteter auf ihre Lebenslagen in Deutschland [Arriving after the escape: The perspective of accompanied and unaccompanied young refugees on their living conditions in Germany]. Deutschen Jugendinstituts. https://www.dji.de/fileadmin/user_upload/bibs2017/25854_lechner_huber_ankommen_nach_ der_flucht.pdf

Mediendienst Integration. (2020). Syrische Flüchtlinge [Syrian refugees]. https://mediendienstintegration.de/migration/flucht-asyl/syrische-fluechtlinge.html 
International Journal of Child, Youth and Family Studies (2020) 11(4.2): 80-95

Meinhold, J. (2019). Erstaufnahme-/AnkER-Einrichtungen sind keine Lebensorte für Kinder und Jugendliche [First reception/anker facilities are not places of life for children and adolescents]. Forum Erziehungshilfen, 5, 266-270. https://contentselect.com/de/portal/media/view/5e159288-3508-4252-8a56-65e4b0dd2d03

Meinhold, J. (2020). Holt geflüchtete Kinder und Jugendliche endlich aus den griechischen Lagern! [Finally get refugee children and young people out of the Greek camps!]. Forum Erziehungshilfen, 4, 195. https://content-select.com/de/portal/media/view/5f6a1922-7cdc4bdc-8606-1280b0dd2d03

Mühlmann, T. (n.d.). Inobhutnahmen zum Schutz von Kindern und Jugendlichen. bleiben auf hohem Niveau [Taking into care to protect children and young people remains at a high level]. Deutsches Jugendinstitut. https://www.dji.de/themen/kinderschutz/inobhutnahmen-zumschutz-von-kindern-und-jugendlichen-bleiben-auf-hohem-niveau.html

National Coalition Germany. (n.d.). Network for the implementations of the UN Convention on the Rights of the Child. https://www.netzwerk-kinderrechte.de/en.html

Oppel, C. (2019). Masterthesis: Vorläufige Inobhutnahme und Verlegung von unbegleiteten minderjährigen Flüchtlingen in Deutschland-Empirische Befunde aus der Online-Umfrage des BumF e.V. und professionspolitische Überlegungen [Preliminary taking into care and relocation of unaccompanied minor refugees in Germany - empirical findings from the online survey by BumF e.V. and professional policy considerations; Unpublished master's thesis]. Katholische Hochschule für Sozialwesen Berlin [Catholic University of Social Sciences, Berlin].

Paritätischer Gesamtverband. (2019). Das Recht auf Bildung und Zugang zur Regelschule für geflüchtete Kinder und Jugendliche in Aufnahmeeinrichtungen der Bundesländer [The right to education and access to regular schools for refugee children and young people in reception centers in the federal states].

http://infothek.paritaet.org/pid/fachinfos.nsf/0/03243c26e624ea20c12584b0002db1d6/\$FILE/ Gutachten_Paritätischer_Zugang_Regelschule_Kinder_Aufnahmeeinrichtungen.pdf

Peters, F. (2016). Wem gehört die Stadt [Who owns the city]? Forum Erziehungshilfen, 5, p. 259.

Peters, F. (2018). Reich werden durch Armut? Das Elend der Unterbringung Geflüchteter [Getting rich through poverty? The misery of housing refugees]. Forum Erziehungshilfen, 1, 3.

Sozialgesetzbuch VIII. (n.d.). Social code: Book VIII (Child and Youth Care Act — SGB VIII). https://www.sozialgesetzbuch-sgb.de/sgbviii/1.html 
International Journal of Child, Youth and Family Studies (2020) 11(4.2): 80-95

Struck, N. (2014). The insular immigration society. DJI Impulse [Special English Edition]: Living and surviving, 21-22. https://www.dji.de/fileadmin/user_upload/bulletin/e_bull_e/bull2014_e/DJIB_2014.pdf

Struck, N. (2016). Flüchtlinge in den Handlungsfeldern der Kinder- und Jugendhilfe [Refugees in field of child and youth welfare]. neue praxis Sonderheft, 13, 126-135.

Struck, N. (2017). Jugendhilfepolitische Entwicklungsperspektiven [Youth welfare policy development perspectives]. In S. Brinks, E. Dittmann, \& H. Müller (Eds.), Handbuch unbegleitete minderjährige Flüchtlinge [Handbook for unaccompanied minor refugees] (pp. 312-324). International Society for Educational Aids (IGfH).

Struck, N. (2019). Junge Flüchtlinge: ihr Recht auf Bildung und wie ihre Zurichtung auf Abschiebung hin funktioniert [Young refugees: their right to education and how they are prepared for deportation]. Forum Erziehungshilfen, 1, p. 3)

Tangermann, J., \& Hoffmeyer-Zlotnik, P. (2018). Unbegleitete Minderjährige in Deutschland. Herausforderungen und Maßnahmen nach der Klärung des aufenthaltsrechtlichen Status. Studie der deutschen nationalen Kontaktstelle für das Europäische Migrationsnetzwerk $(E M N)$ [Working paper 80; Unaccompanied minors in Germany. Challenges and measures after clarification of the legal residence status. Study by the German national contact point for the European Migration Network (EMN)]. Bundesamt für Migration und Flüchtlinge. https://www.bamf.de/SharedDocs/Anlagen/DE/EMN/Studien/wp80-unbegleiteteminderjaehrige.pdf? blob=publicationFile \&v $=18$

taz. (2019, November 1). \#European Homecare. https://taz.de/European-Homecare/!t5010140/

Terre des hommes. (n.d.). Geflüchtete Kinder in Deutschland: Schutzlücken werden größer

[Refugee children in Germany: Protection gaps are widening], https://www.tdh.de/fileadmin/user_upload/inhalte/04_Was_wir_tun/Themen/Krieg_und_Fluc $\underline{\text { ht/Fluechtlingskinder_Schutzluecken_werden_groesser.pdf }}$

UNHCR. (2020). Statistiken. https://www.unhcr.org/dach/de/services/statistiken

United Nations Convention on the Rights of the Child, November 20, 1989. https://www.ohchr.org/en/professionalinterest/pages/crc.aspx

United Nations Office on Drugs and Crime. (2004). United Nations Convention Against Transnational Oranized Crime and the Protocols Thereto. https://www.unodc.org/documents/treaties/UNTOC/Publications/TOC\%20Convention/TOCe book-e.pdf 
International Journal of Child, Youth and Family Studies (2020) 11(4.2): 80-95

UNICEF. (2017a). A child is a child: Protecting children on the move from violence, abuse and exploitation. https://www.unicef.de/blob/141422/acaf7e52cf898706ebbfc71702fb471c/achild-is-a-child--unicef-report-17-05-2017-data.pdf https://www.unicef.org/publications/files/UNICEF_A_child_is_a_child_May_2017_EN.pdf

UNICEF. (2017b). Zahl der Unbegleiteten Minderjährigen Flüchtlinge und Migranten Hat Sich Seit 2010 Verfünffacht [The number of unaccompanied minors refugees and migrants has increased fivefold since 2010]. https://www.unicef.de/informieren/aktuelles/presse/2017/zahlminderjaehriger-fluechtlinge-steigt/141102

UNICEF. (2018). Geflüchtete und migrierte Kinder in Deutschland - Ein Überblick über die Trends der letzten drei Jahre [Refugee and migrant children in Germany: An overview of the trends of the last three years]. https://www.unicef.de/blob/178376/1637bee598b37086a9c0a5110419a95c/gefluechtete-undmigrierte-kinder-in-deutschland-2015-2018-data.pdf

Wikipedia. (2018). Liste Flüchtlingsfeindlicher Angriffe in Deutschland 2018 [List of antirefugee attacks in Germany 2018].

https://de.wikipedia.org/wiki/Liste_flüchtlingsfeindlicher_Angriffe_in_Deutschland_2018

Wikipedia. (2019). Liste Flüchtlingsfeindlicher Angriffe in Deutschland 2019 [List of antirefugee attacks in Germany 2019]. https://de.wikipedia.org/wiki/Liste_flüchtlingsfeindlicher_Angriffe_in_Deutschland_2019

Wikipedia. (2020). Flüchtlingsunterkunft (Deutschland) [Refugee accommodation (Germany)]. https://de.wikipedia.org/wiki/Fl\%C3\%BCchtlingsunterkunft_(Deutschland)

Willems, D. (2020). Viktimisierungserfahrungen junger Geflüchteter [Victimization experiences of young refugees]. Deutsches Jugendinstitut. https://www.dji.de/fileadmin/user_upload/jugendkriminalitaet/Viktimisierung_Junge_Gefluec htete_DWillems.pdf 